\title{
Symptoms of Depression among Teenagers in Malaysia
}

\author{
Intan Farhana Saparudina, and Siti Nabilah Che Soh \\ A \\ Centre of General Studies and Co-Curricular, Universiti Tun Hussein Onn \\ Malaysia, Batu Pahat, Johor. \\ ${ }^{\mathbf{b}}$ Faculty of Applied Science and Technology, Universiti Tun Hussein Onn \\ Malaysia, Batu Pahat, Johor.
}

Article History: Received: 11 January 2021; Accepted: 27 February 2021; Published online: 5 April 2021

\begin{abstract}
Depression is a psychiatric disorder that involves emotional disorders that often occur in Malaysian teenagers. Depression will cause a person to feel sad, tired, and angry, lose interest to do daily activities and tend to kill themselves. Depression can occur in male and female teenagers. It is often a sad feeling that occurs in a long period so that it can reach a period of two weeks. Symptoms of depression can be seen from the angle, cognitive, behavioural and physiology associated with each other in their daily lives. Teenagers are also not spared to face depression. In a variety of emotions facing teenagers, they face a variety of emotions that make them depressed and will result in depression. The objective of this article is to identify the symptoms of depression suffered by teenagers. To identify the objective of the content analysis method is done. The findings show that there are some symptoms of depression that cause discomfort and disrupt teenagers to function normally. The implication of the study giving knowledge about the symptoms of depression among teenagers and the kinds of treatment often used which are through counselling and psychotherapy.
\end{abstract}

Keywords: Symptom; Depression Teenagers; Counselling; Psychotherapy

\section{Introduction}

Currently, depression is the most widely faced mental disorder in Malaysia (Mohd Hussain and Ahmad Hatim, 2006). At the global level, the World Health Organization (WHO) states that depression is the highest mental disorder experienced in developed countries and developing countries (WHO, 2017; WHO, 2010; Sherina, Arroll, Goodyeay-Smith, Ahmad, 2012). Mental disorders also occur in Malaysia where depression is identified as one of the frequent mental disorders (Firdaus \& Oei, 2011). The results of the National Morbidity Studies Review 2015 by the Ministry of Health, Malaysia found that 29.2 percent of 16 years old individuals had a mental disorder. In Malaysia, teenagers are classified as secondary school students. According to Doe Laile Suzana (1996), teenagers are classified into three levels, namely early teens (12 to 14 years), middle and final teenagers (15 to 19 years old). In the age of teens, they often experience mental and physical disorders such as stress, anxiety, depression, headache and abdominal pain (Hall \& Torress, 2002). This stress and depressed situation will eventually make teenagers suffer from depression when not being addressed effectively.

\section{Literature Review}

\subsection{Depression}

Depression is a psychiatric disorder that involves disturbance in a person's emotions. Individuals who suffer from depression will show a sense of sadness, depression, low self-esteem, despair and blame yourself for things that happen in their lives (WHO, 2017). The sadness experienced by the individual will be prolonged for weeks on (WHO, 2017). According to the Diagnostic and statistical manual of mental disorders 5th Edition (DSM 5), the main criteria for depression is when people show symptoms of depression lasting at least two weeks (APA, 2013). Symptoms usually experienced by an individual are feeling stressed, depressed, sad, loss of interest which last for at least two weeks.

There are some symptoms shown by people who suffer from depression are linked to each other. These symptoms are divided into four main aspects of cognitive, behavioural, physiological and affective. According Haron Din (2011), people will lose heart and conscience due to two things, first is being too disappointed as a result of the failure to have the form of material and second is due to spiritual emptiness of the soul of a great filling. In fact, an individual will suffer from stress, depression and anxiety when faced with the difficulties of life as a result of the conflict itself, interaction with others, or how a person responds to life (The Malaysian Mental Health Association, 2008).

\subsection{Symptoms of depression}

Symptoms of major depressive disorder can be seen from the point of affective, cognitive, behavioral and physiological. The main symptoms of depression are feelings that accompany the decline in activity and the reduction of the patient's condition seemed lifeless (Azizi Yahaya \& Tan Soo Yin, 2007). Patients would show 
instability irrational feelings such as prolonged sadness, depression, melancholy, despair and feel insignificant. This situation will lead to patients not interested in doing any activities that normally take place. Patients will also blame themselves for the failure of a thing (APA, 2013). This is continued until the patient cries to vent sad, disappointed and angry.

Cognitive symptoms showed teenagers with depression mind will be distracted and his mind is filled with events that are sad and disappointing. These patients also tend to think negatively of themselves, others and feel that the future is dark (Haji Bond, 2008). These kinds of feeling will also causea prolonged loss of interest in activities that patient enjoys doing and eventually he cannot pay attention to events as often harassed by anxiety and fear that is experienced due to depression (Azizi Yahaya \& Tan Soo Yin, 2007). They also tend to think negatively of the future and feel the grief experienced will not end hence they also tend to commit suicide in order to solve all the problems. Patients also often experience symptoms such as difficulties for rational and easy to lose focus.

Teenagers who suffer from depression will often cry, frail, shy away from the crowd and will show deterioration in terms of education. These patients will also experience a impairment in psychomotor activities such cannot sit still and their movements will be slow and immobile for prolonged periods. There are also patients who show changes in speech, tone of voice and difficulties to respond to a conversation.

Typically, teens with depression will face the physiological symptoms such as loss of appetite and weight loss, and will suffer from constipation. But, there are also patients of whose appetite leads to weight gain. They will also experience sleep problems, namely either insomnia or hyper insomnia. Insomnia can occur in three stages, namely an initial stage where the patient will have difficulty sleeping. The intermediate level happens when patients often wake up late at night and face difficulty to sleep again. In the third phase, the patient is awake early in the morning and find it difficult to sleep back. However, there are some patients who suffer from insomnia, who sleep excessively either at night or during the day. There are also teenagers who suffer from menstrual cycle. In addition, there are also patients who show a decrease or loss of interest in sex.

\subsection{Categories of depression:}

According to the Diagnostic Statistical Manual of Mental Disorders 5th Edition, (APA, 2013), the major depressive disorder can be categorized into eight as:

1. Disruptive Mood Dysregulation (DMDD),

2. Major Depressive Disorders (MDD),

3. Persistent Depressive Disorders Dysthymia,

4. Premenstrual Dysphoric Disorders,

5. Medication-induced depressive disorders),

6. Depressive disorders due to another medical condition,

7. Other specified depressive disorders and

8. Unspecified depressive ordered.

\section{Methodology}

The method of study is content analysis and literature study. Content analysis examines documents and literature reviews on depression aspects that can be featured as a guiding step towards adolescent behaviour. According to Sabitha Marican (2005), content analysis is a form of quantitative research method that makes objective, systematic and quantitative description of an explicit content contained in the form of communication that is a message that has been printed, broadcast or depicted.

\section{Findings and Discussions}

Depression is an unbalanced disorder of emotion where it is usually an individual who faces frustration or stress in their daily lives (Bee, 2004). Depression is said to be different from age and gender. The result of the study by Blazer et al., (1994) in Nevid et al. (2000) stated that the level of depression is a rate of rare increase in person's age. Through a study of Angold and Rutter, (1992) and Lorenz et al., (1994) in Petersen et al. (1991), the findings of the study are consistent with the pattern of age differences in children and occur at age after 10 years and before reaching 15 years. Gorenstein et al., (2005) found the most significant increase from the age of 13 years $($ mean $=$ $8.00)$ to 17 years $($ mean $=10.20)$ Where this study was performed against a non-clinical teenager in Brazil with a sample of 1555 school teens.

In the study of Shaffer et al., (1996) where the researchers use the surgical method to investigate psychological aspect found that $60 \%$ of the performers had at least one disorder and most had depression disorder (Karaman \& Durukan, 2013). Women tend to face high depression disturbances if the pressure or problems occurred in connection with the interpersonal relationship (Girgus, 2015). According to Hammen (2009), women who have experience of depression at the age of teenagers will have a recurrence of the disorder of depression at adult age. 
According to Rudolph and Hammen (1999), the symptoms of depression are increasing at the age of teenagers than at the age of the child. Meanwhile, according to Nolen-Hoeksema and Girgus (1994) teenagers who are at risk of having depression are those at the age of 11 to 15 years old.

A high depression disorder occurs in the women's youth during the age of puberty due to significant changes to oestrogen hormone levels. Oestrogen hormones are hormones produced by the female reproductive system associated with the development of women during puberty. Oestrogen hormones are also required to increase the serotonin hormone, which is the chemical liquid found in the human brain structure that serves to stabilize the mood. When teenagers are decreasing the serotonin hormone, this will result in individual mood changes and consequently will result in the occurrence of depression.

According to Albert (2015), depressive disorders among women and men often occur. According to Frydenberg and Lewis (1991), when faced with stressful situations, young women are more qualified to give and receive social support compared with boys. Teenage girls are more likely to be surrendered to fate and escape from the stressful situation. Compared with boys, they become more aggressive and secretive. In conclusion, according Blehar and Oranges (1995), approximately two-fold problem of women are affected by depression than men.

For the rehabilitation and treatment, there are various methods used for patients mental of which is the support of friends and family members. In addition, patients can get a medical treatment, counselling and psychotherapy, and social activities through religious approach (Braunholtz S et al., 2004). According to the Malaysian Mental Health Association or MHA (2012), the treatment for mental illness is addressing which includes physical, psychological and social treatments. In addition to the drugs given by the hospital, the use of electric current (electro conclusive therapy) may be required for some patients who are depressed or aggressive that do not respond to drugs.

The main treatment that is often used is through counselling and psychotherapy. Counselling can help patients understand their condition and feelings more closely. Patients going through some counselling sessions and the amount depends on the individual needs. Whereas for psychotherapeutic treatment, this treatment is a treatment involving both doctor and patient. According to Amina (2009), one form of psychotherapy is Dynamic Psychotherapy, Cognitive Psychotherapy and Psychoanalytic Psychotherapy. According to Azizi Yahya \& Soo Yin (2007), electroconvulsive treatment (ECT) is supplied through a low voltage electric conduction across a person's brain. This type of treatment is safe, harmless and is often used to treat serious depression.

For the treatment of depression from a spiritual point of view, according to Paragament and Park (1995), religious treatment can control the pressure felt. Religion is closely related to the methods and implementations. Moreover, religious life and practice to provide guidance on any individual action when either individually or collectively. According Dein (2006), after making an analysis of the database of research related to religion and depression through study ever published by PubMed, PsycINFO and Medline from 1996 to 2006 found that patients who practiced the religion had a lower rate of symptoms of depression. The study also found to be religious people can add speed to recover from the pain experienced.

According to Islam, in restoring mental health treatment, there Islam is a need to strengthen and renew the spirituality or spiritual aspects of the individual (al-Zahrani, 2005). According to Koenig (2002), there are five reasons why the spiritual aspect of mentally ill patients are important. The first is the mental patients are among religious people. Second, trust and faith influence decisions, especially for those with chronic pain. Thirdly, do religious activities related to the health and quality of life. Fourth, many patients require the therapist to focus on the elements of their spirituality. Fifth, the perspective that the spiritual approach related to health is not something new in the treatment of patients.

\section{Conclusion}

Depression among teenagers is not a new one. The symptoms indicated by patients with depression can be seen in several aspects through the patient's behaviour, cognitive, affective and physiology. However, teenagers should have the power to reduce the disease of depression. According to Yusliza Mad Yusuf (2004), she noted that most female students who were studying at the Institute of Higher Learning used an initiative to reduce stress. The strategy used is a social relationship among friends as when they were in a non-situation, social relationship responses were used such as religious support, relationship with friends and so on. Through religious support, the female students were able to increase their prayers and worship to calm their hearts. While through socializing, the female teenagers were able to share problems to trusted friends. According to Mastura Mahfar, Fadilah Zaini and Nor Akmar Nordin (2007), the spiritual aspect of religion-related matters is the third highest to be used by 47 per cent of the respondents facing stress. Among the activities practiced by the respondents were to engage in Allah, making practices claimed in Islam, established a compulsory and religious prayer, reading the Qur'an, taking ablution praying to Allah and self-esteem. As a Muslim, this strategy should be used to restore mental health and reduce pain and regain peace.

\section{Acknowledgement}

This article is based upon research supported in part by the Fundamental Research Grant Scheme (FRGS), under project vote: K0610 FRGS / 1/2018 / SS05 / UTHM / 03/2, University Tun Hussein Onn Malaysia and Ministry of Higher Education, Malaysia. 


\section{References}

1. Albert. P. R. (2015). Why is depression more prevalent in women? Journal Psychiatry Neuroscience, 40(4), 219-221. Doi: doi:10.1503/jpn.150205.

2. American Psychiatric Association (APA).(2013). Diagnostic and statistical manual of mental disorders (5th edition). Washington, DC.

3. Amina, H. N. (2009). Kesihatan Mental. Cara Mengenali \& Menanganinya. Kuala Lumpur: Al-Hidayah Publication.

4. Angold, A. and Costello, E.J. (1992). Depressive Comorbidity in Children And Adolescents: Empirical, Theoretical And Methodological Issues. Am J Psychiatry 1993; 150: 1779-1791.

5. Azizi Yahaya and Tan Soo Yin (2007). Kesihatan Mental). Skudai. Penerbit UTM

6. Blehar, M.C., \& Oren, D.A. (1995). Women's increased vulnerability to mood disorders: Integrating psychobiology and epidemiology. Depression, 3:3-12.

7. Braunholtz S et al. (2004). Well What Do You Think. The Second National Survey of Public Attitudes To Mental Health, Mental Well-Being And Mental Health Problems. Edinburgh.

8. Dein, S. (2006). Religion, Spirituality and Depression: Implications for Research and Treatment. Primary Care and Community Psychiatry, 11(2), 67-72. Retrieved from http://yuschoolpartnership.org/attachments/article/86/religionasprotectionfromdepression.pdf

9. Firdaus, M., \& Oei, P., S. (2011). A Review on the prevelence of depression in Malaysia. Current Psychiatry Reviews, 7(3), 1-5.

10. Frydenberg, E., \& Lewis, R. (1991). Adolescent coping: The different ways in which boys and girls cope. Journal of Adolescent, 14, 119-133.

11. Gorenstein, C.G., Andrade, L., Zanolo, E. and Artes, R. (2005). Expression Of Depessive Symptoms In A Nonclinical Brazilian Adolescent Sample. The Canadian Journal On Adolescence.1. 63-91.

12. Girgus, J.S. \& Yang, K. (2015). Gender and depression. Journal current opinion in Psychology, 4, 53-60. Doi: doi.org/10.1016/j.copsyc.2015.01.019.

13. Haji Bon Nissa Md. Abdul Kadir (2008). Kemurungan Selepas Bersalin Di Kalangan Wanita: Satu Kajian Kes. Projek Sarjana Muda. Skudai: UTM.

14. Hammen, C. (2009). Adolescent depression. Annual Review Clinical Psychology, 1, 293-319. Doi: 10.1146/annurev.clinpsy.1.102803.143938.Hall, A.S., \& Torres, I. (2002). Partnerships in preventing adolescent stress: Increasing self esteem, coping, and support throught effective counseling. Journal of Mental Heath Counseling. 24(2), 97-110.

15. Haron Din. (2011). Rawatan Penyakit Rohani. Bandar Baru Bangi: Persatuan Kebajikan \& Pengubatan Islam Malaysia

16. Jas Laile Suzana Jaafar. (1996). Psikologi kanak-kanak dan remaja. Kuala Lumpur : Dewan Bahasa dan Pustaka.

17. Koenig, H.G. (2012). Spirituality In Patient Care. Why, How, When and What. Pennsylvania: Templeton Foundation Press.

18. Mohd. Sufian Omar Fauzi (2004). Psikologi Kejurulatihan Membantu Membina Ketahanan Mental Atlet. Selangor: Karisma Publication.

19. Mohd Hussain Habil dan Ahmad Hatim Sulaiman (2006). Kemurungan: Punca Dan Rawatan. Kuala Lumpur: UM

20. MMHA. (2008). What Is Mental Health? Kuala Lumpur: Malaysian Mental Health Association.

21. Nevid, J.S., Rathus, S.A., and Greene, (B.2000). Abnormal Psychology in A Changing World. 4th Edition. Jersey: Prentice Hall.

22. Nolen-Hoeksema, S., \& Girgus, J.S. (1994). The emergence of gender differences in depression during adolescence. Psychological Bulletin, 115, 424-443.

23. Pettersen, A.C., Sarigiani, P.A., and Kennedy, R.E. (1991). Adolescent Depression : Why More Girls? Journal Of Youth And Adolescence, 20(2), 247-271.

24. Rudolph, K. \& Hammen, C. (1999). Age and gender as determinants of stress exposure, generation, and reactivity in youngsters: a transactional perspective, Child Dev, 70, 660-677.

25. World Health Organization. (2012). Depression A Global Crisis. World Federation for Mental Health. U.S.A. from http://www.who.int

26. World Health Organization. (2017). Depression and other common mental disorders: Global health estimates. World Health Organization. Geneva. From http://www.who.int/mental_heath/management/depresssion/prevalence_obhealth estimates/en/. 